
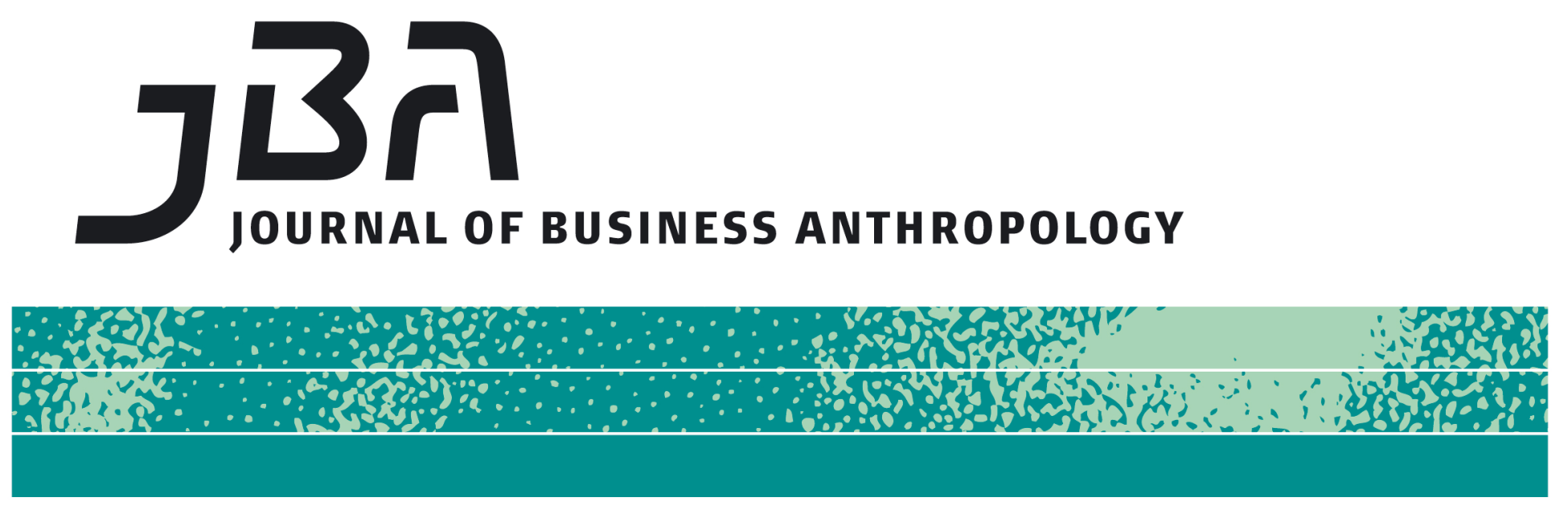

\title{
Fieldwork in a Hall of Mirrors: An Anthropology of Anthropology in Business
}

\author{
Jakob Krause-Jensen
}

\begin{abstract}
An increasing number of anthropology graduates find employment in business organisations, often as culture experts or consultants drawing on ethnographic methods. In this paper I will use my fieldwork experience in the Human Resource Department of Bang \& Olufsen to explore the borders and crossovers between anthropological research and anthropological consultancy. Fieldwork took place among human resource consultants (some of them with an anthropological background) who worked for business, i.e. who used ethnographic methods and worked on identifying, describing and communicating the fundamental corporate values, or, as it were, the 'corporate religion' of the company. How does it affect research stratagems and methodology when the HR employees are in a clear sense both participants in and observers of their own social reality? Is it at all feasible or possible to maintain a distinction between ethnographer and consultant, participant observers and observing participants? Although the distinction between ethnographer and employee cannot be drawn easily, I want to argue that the fact that it is impossible to maintain a watertight separation does not imply that we should abandon the attempt to make the distinction. Being aware of the similarities and overlaps as well as acknowledging the differences is a crucial part of the anthropological methodology.
\end{abstract}

Page 1 of 19

JBA 6(1): 102-120

Spring 2017

(C) The Author(s) 2017

ISSN 2245-4217

www.cbs.dk/jba 


\section{Keywords}

'pure' and 'applied' anthropology, human resource management, ethnography, corporate culture, reflexivity, role-ambiguity.

As testified in the earlier volumes of this journal a productive tension defines the field of business anthropology: the distinction between those doing anthropology of business and those doing anthropology in or for business. This difference was also the point of departure for the 2012 American Anthropological Association (AAA) workshop 'Anthropology of versus anthropology for business: Exploring the borders and crossovers between an anthropology of business and anthropological consultancy' organised by the editor of this special-edition for JBA. I approach the theme from the vantage point of an academic anthropologist doing research of business. My fieldwork, however, took place in the Human Resources Department of Bang \& Olufsen among consultants-and some of them with an anthropological background-who worked for business. An important part of their job was to work with and communicate the fundamental corporate values or 'the corporate religion' of Bang \& Olufsen, a work towards which they often took an ironic stance. Doing ethnography among Human Resources staff, who worked on identifying and communicating the culture of Bang \& Olufsen, yet who also said that they were not fully part of it-was not a straightforward matter. The study quickly became a meta-commentary, offering my interpretation of some people's reflections on other people's perspectives on what they claimed was the essence of Bang \& Olufsen. Getting to the bottom of things is not an option in such a hall of mirrors and even mapping people's points of view is not a simple matter. Through examples of analysis I intend to show that despite overlaps and striking similarities between them and me there were important differences in the conditions and aims of our work.

\section{The human resources department}

Bang \& Olufsen is a Danish producer of exquisite audio-visual home electronics. Around the millennium the company was putting efforts and resources into defining and communicating its values and vision in the effort to establish a 'corporate religion'. The Human Resource Department had just been formed a few months prior to my fieldwork and was intended to play an important strategic role in the process. This new department was a fusion of the Personnel Department ('medarbejdercenteret') and a Human Resource Development unit. The new and larger HR department comprised a little short of 20 employees covering many different tasks: recruitment of salaried employees, inservice training, internal information (corporate newsletters and magazines), and more strategic work: management consultancy, planning 
and executing management training programmes - and identifying and communicating corporate culture, i.e., the values and the vision. I was mainly interested in this last part: How is anthropology's signature concept put to use in a corporate context? How is corporate culture defined and how are company values communicated? And how do employees negotiate these ideas in their daily working lives?

When I started fieldwork and explained that I intended to do a study of corporate culture, many of my HR 'colleagues' thought I had made a bad choice and advised me to go elsewhere. One suggested that I should pay attention to the relationship between the company and the retailers; another recommended that I spend time in Product Development, where I would find 'the Bang \& Olufsen DNA'; and a third colleague told me that if I wanted to investigate Bang \& Olufsen's culture, the Human Resources Department was not the right place to do fieldwork-'reality is down there, not here [in the HR Department]', she said and nodded toward the factory building. In the view of these employees and as indicated by culture's etymological roots of 'cultivation', 'culture' took time and stability: In the course of fieldwork I spent three weeks working on the shop-floor- and factory demographics were quite different from those of the salaried staff. The workers here were mostly natives from Struer and surrounding towns and villages. Siblings and cousins worked there- as had mothers and fathers and grandparents before them- 'It is possible to draw kinship charts in Factory V', as Søren (an HR consultant with an anthropology background) once remarked. So, in spite of official claims that the company was selling 'not televisions but values', Bang \& Olufsen culture was associated with the factories and Product Development. Bang \& Olufsen culture was thought to be located in the departments and among the people who worked with the actual product and who had a long history with the company. In the same vein, many of the employees described their work environment in the Human Resources Department as one step removed from 'reality'. Birger, who was a senior HR-consultant, expressed a common sentiment, when he said: 'HR has removed itself from the workaday world of the average Joe. Some wires are cut, and the balloon flies away: culture, values, vision ... it quickly becomes "meta", slightly unreal'.

The Human Resources Department was clearly 'meta' in the sense that it was not directly involved in the development and manufacturing of the actual products. In another sense, however, it was very much a part of organisational 'reality': it was the explicit strategy of Bang \& Olufsen to move from being 'product-driven' to being a 'vision and value-driven' company. This implies an organisational priority on the less tangible and concrete, an insistence on developing the 'Brand', and a corresponding emphasis on 'communication' and marketing as areas of strategic importance. The areas concerned with the 'metaphysics' of the products, 
the work of defining and communicating the values of the organisation, were receiving growing attention and resources-and in this sense assuming more and more reality. These strategic priorities were reflected in the fact that when I started fieldwork, the company was in the middle of communicating a set of 'fundamental values' that had recently been identified to employees, subsidiaries, retailers, and corporate stakeholders, and a process of articulating a corporate 'vision' had just started. Furthermore, HR was situated on the 3rd floor of the new administrative headquarters, just outside CEO Anders Knutsen's office, and 'communication' (including HR) was now his direct responsibility. But even if HR is very visible and close to management, and some HR employees had work that gave them contacts around the organisation, the fact was that HR-like other staff functions-had very little power.

In the corporate magazine Beolink (1999, p. 14-16), Peter described his own role as an HR consultant in the company:

People's attitudes towards me can be divided into two categories:

1. I'm a tool of the management to manipulate the staff.

2. I'm here to protect the staff from the company.

They're both wrong. I'm on the side of the work. Both the staff and the company share an interest in ensuring that the staff gets the most out of their work and that the company gets the most out of its staff.

\section{THE MEANING OF LIFE}

If I look at people's motivation for working, it's all about them wanting to make a difference ... Few people enjoy holding a post or performing a function which doesn't have any real value. People need to feel that it's important that they carry out their job successfully and that it matters whether they do it well or badly ... This requires a management, which takes an interest in whether there is a point to what each individual is working on-anything else would not be reasonable both from a commercial point of view and in terms of the individual's self-esteem.

It's important that managers know where employees fit into things, and it's vital that progress is noted and development monitored-so that people can see that their work is useful.

As testified in Peter's self-presentation, the HR consultants were meant to act as brokers between corporate aims and worker concerns. Hanne, another HR consultant, acknowledged this middle-man role by using the word 'scout' to explain her job-occasionally HR would be treated as messengers, who could give (unofficial) information on recent developments in management circles. They would sometimes trade information, and make employees understand that they were not part of 
management, but on the other hand give management just enough information not to be deceptive or disloyal. Frank, who was one of my key informants, described this position as a relay between 'management' and 'organisation'.

FRANK: "[Sometimes I had] some pretty close and intimate relations to some of these managers through the conversations I had with them. Well in those cases there was a special relation, which went far beyond the professional. In that way I could, sort of...like a spider, I could draw information from the whole [organisation]. I knew what was going on in the organisation, if something was brewing-I could gauge moods ... We are undercover agents for senior management...If something was under way it had to be reported to senior management, and all this information. I mean, senior management is very dependent on a Human Resources Department, which always has an ear to the ground and knows what is going on in the organisation."

But if Frank confided to me that he saw himself as an 'undercover agent' - what was I doing, spying on the spy? ${ }^{1}$ The human resource consultant's role was betwixt and between and in this sense resembled the ambivalent position of the ethnographer. Like me, the human resource consultants used concepts and symbols to make meaning. Thus, a key part of their work with values and culture was to devise and communicate appealing images and compelling narratives to motivate employees and help them reflect on their work and role in the organisation.

The fact that in a number of ways I was similar to them also meant that I was able not only to observe but also to participate in their work, as indeed it was an understanding and condition of my presence that I should. Bang \& Olufsen, however, in no way interfered with my research and I was left free to get involved wherever my analytical interests might take me. So I participated in particular projects, provided 'inputs' to strategic papers, helped arrange seminars, and attended meetings much like any other Human Resource consultant. However, when all is said and done, my stakes were different: the university paid my salary, and I didn't have to think about my future career with Bang \& Olufsen. I was not held responsible for the outcome. My ultimate aim was not to come up with a set of fundamental values-I was interested in why they were interested in 'religion' and 'values' and how those interests played a role in their working lives. I wanted to find out how concepts of culture were used in management discourse and practice.

In my analytical work I used similar concepts (value, religion, culture etc.), but my metaphors were not motivational and my description

\footnotetext{
1 The ambiguity of the HR position is explained and analysed in greater detail in Krause-Jensen 2010 and 2013b.
} 
did not have to contribute to the prosperity of the organisation, but to a refinement of understanding through a theoretically embedded discussion (Krause-Jensen 2010, 2013b). Temporalities were also radically different. The long time-span and open-ended, serendipitous qualities of an ethnographic research project was foreign to workrhythms in the HR department. 'The only thing constant is change' was a phrase often invoked to capture corporate existence, and work in the HR department was indeed defined by short time frames and immediate deadlines- Business and busyness were immediate realities.

\section{Need for speed - and call for calm}

Pace in the Western world is generally increasing (Eriksen 2001), and the corporate world is no exception to this speed-up: organisations are under pressure to adapt to volatile stock-markets, ever-changing consumer preferences, and incessant technological innovations. This is true for the manufacturing industry in general but presented a particular challenge for Bang \& Olufsen as the company has built its reputation on the longevity of its products and the durability of its designs (Krause-Jensen 2013a). At the social level-the level of employment relationships-these rapid changes are reflected in frequent re-organisations and increasing calls for flexible work arrangements (outsourcing, subcontracting, consultants, temps. etc.).

The project of determining a corporate identity and defining company values could well be seen as an attempt to counteract these fragmenting tendencies. The need and the attempt to get one's footing under these fluctuating and fragmenting circumstances is what informs efforts to define a strong 'corporate culture'. As Paul du Gay (1996: 1) has put it: 'Identity only becomes an issue when it is in crisis, when something assumed to be fixed coherent and stable is replaced by the experience of doubt and uncertainty...' This is also confirmed by official understandings that the three new values-poetry, synthesis and excellence-were 'fundamental'. They were emphatically not invented but discoveredimplying that this was an archeological rather than an architectural project.

As it happened, however, the new values did not have the effect anticipated by their creators and communicators. It was well-known in the HR-department that the values were not eagerly embraced everywhere. Rather, they were treated with enthusiasm by a few, scepticism by more, and indifference by most. As one engineer from the R\&D division confided: 'They [the group that defined the values] has never 'walked the talk'. The values have been conjured up like some 'signs' rather than something people over here have felt. Over here it is more in the backbone, the sensibilities, the tradition...'

At the conference launching the values and inaugurating the 
newly built headquarters in 1998, CEO Anders Knutsen gave his interpretation of the significance of values:

In an organisation based on rules you can work against the rules and keep yourself at a comfortable distance. When a company starts working by a set of values, you have to decide for yourself whether you're in or out. Some people will be offended by that and suggest that companies are intruding into your personal life and eating up your soul. I don't really know about that, but isn't that what the most exciting companies do to a certain extent, and don't they give a lot of pleasure back? Value-based companies can't exist without people who put their hearts and souls into their work.

Bang \& Olufsen's work on values was embedded in religious imagery. Anders Knutsen's personal mentor was a Dr. Theol. Mogens Stiller Kjærgaard. And Bang and Olufsen's most influential external consultant at that period was Danish Branding guru Jesper Kunde, who had just published his book Corporate Religion (2000). And along with endorsements from Starbuck executive Howard Schultz, Anders Knutsen was quoted on the back of the English edition: 'This well-written book puts into words what we know to be true, and there's no getting away from it. The argumentation and methodology are here. We have no more excuses. It's the book I have been waiting for' (Kunde 2000).

The book is full of millenarian fervor and fundamentalist rhetoric. Resonating with Anders Knutsen's statements above it read:

"When the leader's fire is burning brightly, the next step is a 'bible' which describes the nature of the belief, the set of values and the rules of conduct which apply to all who live in this particular community. This bible is the most valuable management tool of all" (Kunde 2000: 101).

"It might sound totalitarian, but with a clearly defined Corporate Religion there is nobody who will have problems on the course because everybody's job is connected to the company's Corporate Religion-the first criterion for being employed" (Kunde 2000: 103).

"A company which is governed by corporate religion only has jobs for believers (Kunde 2000: 111).

Given such fundamentalist religious rhetoric it is perhaps not surprising that the vision and values were rarely discussed or challenged in public. The Manichean division between believers/non-believers and the dramatic consequences of 'not believing' were never made clear.

\section{Communicating the values}

When I visited Bang \& Olufsen for the first time and explained my project 
to the HR manager, I used the word 'exclusive' to describe the products. When he heard the word 'exclusive' he frowned and, with a joking gesture, stood up and opened his office door: 'The meeting is over. Bang \& Olufsen is not exclusive. It is excellent,' he said with a twinkle in his eye, explaining the difference between 'exclusive' and 'excellent'. The HR manager's dramatic gesture seemed to mock the hair-splitting preoccupation with the meaning of the concepts that went into the official definition of the three values, and at the same time, of course, he demonstrated that he was familiar with canonical interpretations.

I soon discovered that the arms-length attitude towards the fundamental values was characteristic of the way that HR employees referred to the words-maybe to counterbalance the high-flown semantics and elevated level of abstraction that made their everyday use awkward. As one HR consultant once confided:

Many of the words used in this world are so inflated, hyped up, and hysterical (gummiagtige, forskruede og overpumpede) that often you don't know what you are talking about. You find that here as well. It's often a load of bullshit that some smartass in the United States invented to earn a lot of money [...] Bang \& Olufsen doesn't believe that there is anything in the world but the vision, and everybody should know that. But the truth is that Mrs. Hansen in Humlum [small town near Struer] doesn't give a damn what Bang \& Olufsen's vision is.

It is important that such expressions of dissent, for a few notable exceptions, were not concerned with the totalitatarian consequences of being part of a corporate religion. If people felt threatened, angry or alienated, it was rather because of the abstract nature and the pretentiousness in the message rather than their normative or totalitarian implications

One factory manager told me that he thought it would be harmful to communicate the values to the employees in the factories, or 'Operations' as was the local term. Indeed, many managers, especially from Operations, found it very difficult to operationalise the values, to convert them into useful instructions for how to deal with daily problems. They thought the values were too far removed from the reality of work. During an interview, Niels, a factory middle manager, said: 'Just try and go down to the guy that stands in the rain and who loads Avant ${ }^{2}$ into the truck and talk to him about poetry. I don't think you will get away without a black eye.'

Whether because of middle-manager reluctance to transmit the values or not, it is a fact that many, if not the majority, of the employees below the managerial level and outside the Human Resources and Marketing departments did not know the three words: poetry, synthesis

${ }^{2}$ Avant is the name of a large, high-end television. 
and excellence. The abstract nature of the values, and the official claim that the employees 'live them without thinking about them', as a manager from Human Resources told me, seem to render meaningless from any point of view empirical investigations of the extent to which the values are 'reflected in the practices of the employees'.

Despite the efforts to communicate the values, many managers did not remember them, and if they did, they were rarely recalled with the excitement implied in the evangelical discourse. As pointed out above, the general concern was that the value-work had lost touch with 'reality'. As indicated above, the word 'culture', which had been completely eclipsed from strategic thinking, often appeared during interviews in the illicit, backstage discourse as denoting the reality, which was seen to be threatened, overlooked and compromised by the new strategic value- and branding programs.

HR colleagues were well aware how people throughout the organisation felt towards the values. Susan, a woman in her late 50's who had worked in Bang \& Olufsen for 23 years told me that she actively made a point of not mentioning the values when she had assignments in other parts of Bang \& Olufsen. Referring to one of the three fundamental values, Steen elaborated: 'Ask Allan [head of recruitment] if he would employ someone who described himself as 'excellent'. Puffed up bastard! However good he was he wouldn't make it through the first round'. To add to their embarrassment, however, when HR consultants facilitated larger events like department seminars, managers and employees from the remote parts of the organisation would often feel compelled to refer to and interpret the values-because they imagined that the HR officer expected them to pay tribute to them-and this often led to awkward situations.

\section{The tightrope walk of value talk}

A group of 35 people from the IT department is gathered in a conference room in a hotel an hour's drive from Bang \& Olufsen headquarters. Alex (from HR) and I have been working on the programme for weeks: There was a general feeling among IT staff that their department was marginalised and concerned with 'keeping the wheels spinning', but not appreciated as part of Bang \& Olfusen's success. Furthermore, the department was comprised of groups of employees with different expertise and interests. This morning, Kim Glasgaard, the department manager, was supposed to frame the seminar. We had scheduled his talk as 'the Chief's 'State-of-the-Tribe' speech to his 'Indians'. Kim spoke fluently and without a manuscript. He contextualised the IT Department as part of the overall company, and he started by reminding everyone of the ambitious goals (the mission) contained in the business plan: "The Mission is measurable. We have a target: $10 \%$ increase in turnover per 
year, 15\% increase in profits per year, 100 new B1 shops..." After having lined up the well-known figures from the business plan, he introduced 'the three dirty words' - the fundamental values of the company: Poetry, Excellence and Synthesis. As he mentioned the words, he glanced in the direction of Aksel [human resource consultant] and myself. Compared to the 'facts and numbers'-rationality of the first part of his presentation, he was evidently now on less secure ground: "Most of us probably think that it sounds a bit longhaired ... I think it is necessary to translate the three 'dirty words'. So I want to give you my personal understanding of the three words. As I see it, Synthesis is the same as 'co-operation'. Poetry I understand as 'dialogue', and I understand Excellence to be 'quality'."

Though the chief's speech to his tribe was meant to be a monologue, Magnus, a hot-liner known in the department as a 'loudmouth' (brokrøv) intervened from the back of the room: "To translate 'excellence' by 'quality' —isn't that aiming a little low?" Kim, seeming slightly baffled by the interruption and the subsequent critique, insisted on his version, but Magnus persisted: "As I understand it, quality is about making things that don't break. Excellence is about surprising people, exceeding their expectations-and we don't have many possibilities for doing that in the IT Department! Well, not where I sit anyway." Some giggled quietly, others looked at their coffee cups, not quite sure how to react. Obviously irritated by the persistence of the questions, Kim said: "I think quality covers it nicely, but I don't want to be a preacher on those values. What matters is that we locate and dig up the golden eggs in our department." Someone else from the audience backed up Magnus' interpretation by arguing that MacDonald's was 'quality', but definitely not 'excellent'. Aksel, the consultant from HR, interrupted and reoriented the audience to the frame by humorously suggesting that the 'philosophical debate' be postponed, and asked Kim to continue his speech.

The incident had been embarrassing to us as HR-middlemen; according to official corporate ideology, Magnus was clearly right. It was quite obvious from corporate orthodoxy that 'excellence' had a meaning that, although vague by nature, clearly differentiated the word from the more pedestrian word 'quality'. But, as Aksel told me afterwards, he had chosen not to insist on canonical readings and instead left the matter undecided: in order to help the rest of the two-day programme, he had judged it necessary to help Kim out and try to back up his legitimacy as a leader as far as possible.

As mentioned above many felt uneasy with the values. As one manager told me, he didn't know 'what to do with the values.' It was not difficult to understand why Kim had thought it necessary to interpret and flesh out the very abstract values to fit the needs of a department generally concerned with implementation of big pre-defined IT systems as well as keeping corporate IT running as smoothly as possible 
("driftsopgaver") i.e., 'whose primary task was to be invisible', as one senior manager had put it. Kim's interpretation of the values was not a result of intellectual deficiency or inability to comprehend the ideas behind the values. For the past year, the IT Department had been struggling to meet the deadlines for the company-wide introduction of the SAP programme. It was difficult, then, for the employees to imagine themselves as an 'an integrated part of Bang \& Olufsen's success.' For the values to be rendered meaningful at all in a work environment characterised by tight schedules, time pressure, and 'fire-fighting', the words 'poetry' and 'excellence' called for radical reinterpretations.

\section{Bold visions and double binds}

It was difficult to distil any precise prescriptions from the values, and the vision contained an ambiguous message and paradoxical injunction: 'Courage to challenge the ordinary in pursuit of surprising, long-lasting experience'.

In fact, the organisation was asking 'members' to speak out loud, to transgress or challenge it. But, according to more experienced observers, in general people did not speak out clearly. After a meeting in which the vision had been presented to staff from HR, senior consultant Svend-Erik said:

'But the vision is hot air. What the organisation really wants are docile individuals. We have often seen it. When someone is standing up against the organisation, they are out! If someone falls out, they are dismissed. Look at the former senior managers, look at our marketing manager, look at the head of the information department ... the list is long.'

In closed meetings and interviews, and among people they trusted, employees would be quite explicit about their attitude toward cultural strategies, the values, and the vision. But except for a few exceptions, people did not publicly problematise or discuss the corporate strategy. Only a few people had the position and courage to 'face the lion'. Frank, an HR consultant who worked with strategic issues close to senior management told me about courage and fear when meeting the CEO:

FRANK: Courage is what he appreciates most. Many become so chicken shit when they see Anders Knutsen, because he is Mr. B\&O.

JAKOB: Do you have any examples of that?

FRANK: Many. Some managers, like Otto Knagsted from BD. In meetings with me, he would declare that he thought the values were shit, but when Anders Knutsen asked later on: what do you think about the values? He wouldn't hold on to his previously held 
opinion in public, but just kept his mouth shut. Many people are like that. People would sit there fishing: 'What should I say if I want to mean what he means'. But not Ben Joensen [a highly respected factory manager]. He said what he meant, and he meant what he said. He had a large organisation behind him, and he would say exactly what he meant directly to his [Anders Knutsens] face, and Anders respected that.

This example goes to confirm Goffman's (1969: 70ff) and Bourdieu's (1990: 128) point that being excellent is the prerogative of the insider; that displays of courage are often the privilege of the powerful. But apart from direct confrontations there were other strategies for maintaining autonomy and expressing personal opinions available to the less powerful. One of them was the use of humor or irony.

On the front page of a poster-size (A3) leaflet that presented Bang $\&$ Olufsen's new vision (see above) the reader is met with a large picture of Anders Knutsen staring the reader directly in the eye. The words 'wake up!' reads on the display held like a torch in his right hand. In the leaflet, similar large high-resolution pictures of senior executives in suits launch the campaign 'a life less ordinary', a communication campaign supposed to express the values and the vision.

A few days later Jan (an HR consultant with an anthropology background) had made his own commentary. He had cut out the front page, made a transparent copy of the headgear of a Papuan Chief with red feathers and face paint, and mounted it onto the CEO portrait transforming Anders Knutsen into a colourful corporate warrior and thereby establishing a more obvious correspondence between the picture and the point - the overall campaign promise of 'a life less ordinary'. I heard comments as colleagues passed by: Most of the HR employees reveled in the joke and applauded the imaginativeness - and the nerve it took to pull it off. A small group that was drinking coffee and looking at the poster commented on the campaign folder. Another applauded Jan's interpretation and said: 'It IS quite dull. After all they keep telling us that it is not size that matters', as Susan remarked, referring to the large format of the original brochure. Another agreed: 'Yeah. We are to show 'courage' and what comes out are pictures of men in suits'. One added-in a mocking voice-that Jan was playing with fire, and he should take it down before Anders saw it! Obviously, the visual joke was scorning the current communication campaign and criticising official policy. The public attention and comments did not lead Jan to change his display, and his collage stayed on his cubicle wall.

Drawing on previous studies of subversive humor in offices (Taylor and Bain 2003) and on the shop floor (Collinson 1992), one could be tempted to understand such expressions of dissent along the lines of a long and important tradition of 'resistance ethnography' (cf. Willis 1997 
[1977]; Scott 1990). Such interpretations would, however, miss the mark: HR officers, as Bang \& Olufsen employees in general, might resent particular strategies and have negative views of specific managers, but they did not see themselves in opposition to an unjust system of oppression. The humor used is irony, not sarcasm. In a hall of mirrors among middle-class middlemen, the line between the semiotic entrepreneur and saboteur, between the victim and perpetrator is difficult to draw.

\section{Glass and mirrors}

The administrative headquarters had been built just six months prior to my fieldwork and it was here that the human resources department was located. The building was considered state-of-the-art corporate architecture and every once in a while the architect, Jan Søndergaard, who was easily recognizable with his long blond hair and all-black suit, would show visitors around. Apart from the obvious message of 'transparency', the glass and steel building was intended to epitomize Bang \& Olufsen's three fundamental values: poetry, excellence and synthesis. Indeed that was emphasized at the conference inaugurating the three values and the newly built headquarters. ${ }^{3}$

The glass building or 'glass cage' (see Figure 1), however, is also a strong and suggestive symbol of power, whose meaning and analytical potential becomes clear when held up against two famous metaphors of power: Weber's 'iron cage' (Weber 1991: 182ff.) and Foucault's 'panopticon' (Foucault 1977). By using the metaphor of 'the iron cage', Weber wanted to emphasise that the process of rationalisation epitomised in the efficiency of bureaucracy had happened at a cost. Rationalisation, for Weber, is not a win-win game. The rule-governed efficiency of bureaucracy offered some kind of freedom, but its disenchanted environment of experts 'without heart' (Weber 1991: 182) created other forms of imprisonment. Like the army, it was clear lines of authority and strict adherence to objectified rules that described the iron cage-and for Weber one other crucial characteristic of bureaucracy was also the absolute separation of the 'personal' from the 'professional'.

3 The conference had Edgar Schein as keynote speaker. 


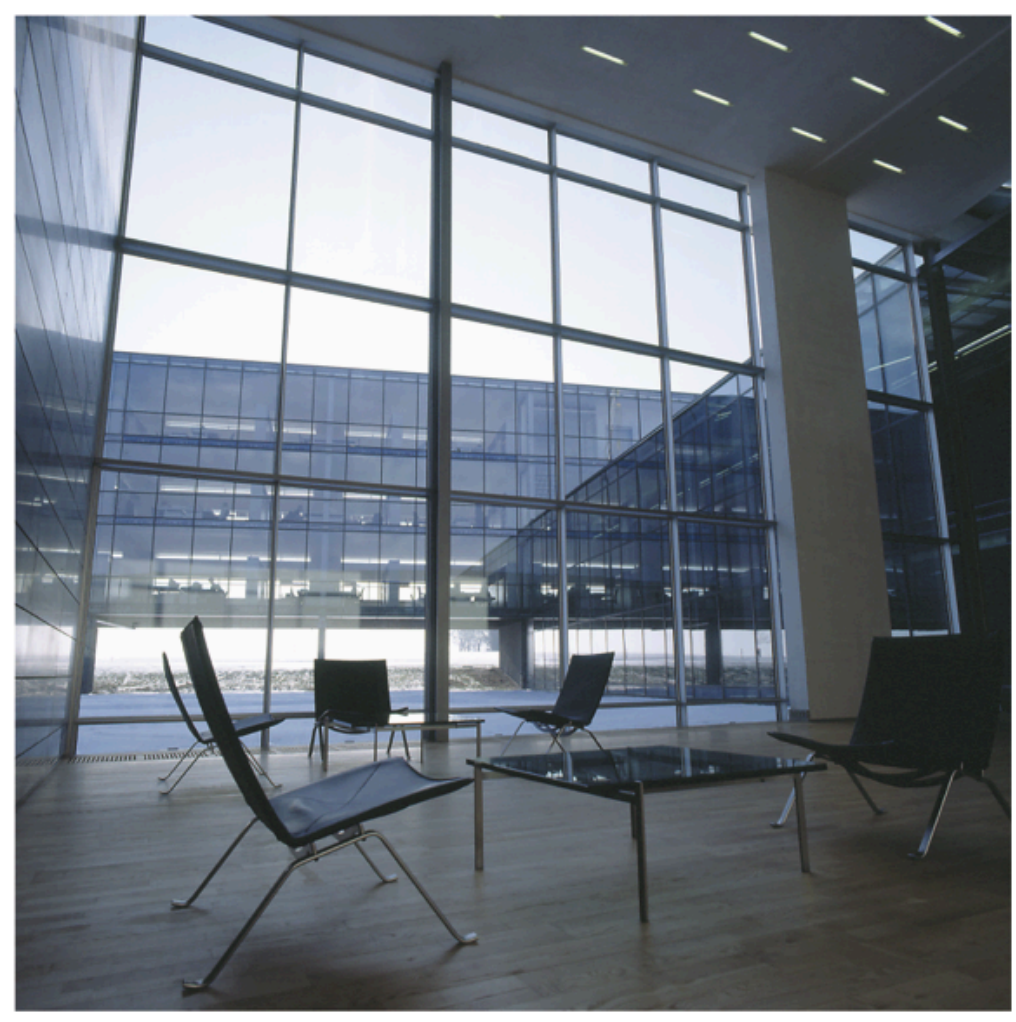

Figure 1: The Human Resource department is situated on the top and third floor of Bang \& Oufsen's new administrative headquarters (photo credit: Jakob Krause-Jensen, Bang \& Olufsen)

The glass cage sends a different message. Contrary to the iron cage, the 'glass cage' suggests the idea of a 'greenhouse', which encourages and inspires both professional and personal growth. The ideal of the value-based organisation implies the fusion of the personal and the professional. Work should provide the employees with the possibility to express themselves as full human beings. In the flexible, value-based network organisation, it was an explicit intention to avoid the rigidity of rules aiming instead at constant adaptive change and development. Glass is of course also a medium of reflection. The ideal is the self-managing employee and in order to become such it is necessary to learn to reflect upon yourself and obtain the soft skills required to function in a network or a team. The glass cage thus emphasizes the importance of demonstrating personal capacities and versatility in social relations. For instance, at the time I did my fieldwork Daniel Goleman's 'Emotional Intelligence' was circulated among staff in the HR department-rumours had it that the CEO Anders was reported to have read it. It was a book that emphasized the importance of emotional reflexivity and self-awareness and ability to empathize as fundamental prerequisites for becoming an accomplished leader (Goleman 2005: 46). Concurrently, the Young Talent's programme for prospective leaders included not only seminars on management in business schools, but also involved participation in 
experimental theatre workshops and philosophy seminars-and the writing of 'learning letters' - indicating that the ideal organisational member or leader should be reflexive and ready to make his personal experience bear upon his working life.

Glass is a material that is used to define and symbolically frame that contained by it as something deserving attention. Actually, the image of the glass cage suggests that it may not be a cage at all, but instead a showcase aiming at highlighting what it contains rather than constraining or oppressing it. The glass cage can be used to imply that, contrary to the 'disenchantment of the world' suggested by Weber (1991 [1904]: 182), what could be seen in Bang \& Olufsen was a re-enchantment of the world. Consultants and managers at Bang \& Olufsen talked about mission, vision, and passion and 'corporate religion'. Emotion and fantasy are not subdued here. They become crucial ingredients in a consumer-driven capitalism (see also Klein 1999).

As a material, glass is at once enchanting, but by the same token also deceptive and ambiguous. Glass is a distorting medium in which light is reflected and dizzy effects created. The glass cage may give ideas of unrestricted freedom, but if acting on those ideas, we will at some point inevitably discover the boundaries and find out that glass is also a very hard material. This was painfully and literally illustrated once during fieldwork when the HR manager suffered a concussion from walking into a glass wall.

With respect to the discreteness and invisibility of power, the glass cage resembles 'the panopticon', Foucault's famous allegory of disciplinary society (Foucault 1977). An allegory that has by now-just like the power it describes-become all pervasive within the social sciences. The point of the panoptic prison is that the prison guard is positioned in a watchtower in the centre of the building. He is invisible from the cells, but from his central spot he can see all of them. The idea is to create in the prisoners a feeling of being under permanent supervision, so that they gradually internalize the gaze of the system and behave as if they were in fact permanently watched. Clearly, the glass cage with its open office landscape, like the Panopticon, offers possibilities of supervisory surveillance.

But in some important aspects, the glass cage is also a transformation and even an inversion of the panoptic prison and a challenge to Foucauldian notions of discipline. The glass cage is not just the site of an indiscernible, managerial omnivision. On the contrary, in the case of Bang \& Olufsen, it is the administrators, the staff, i.e. the 'prison keepers', who are exposed to being watched as well. The HR Department, the Information Department, and the CEO are housed at the top of the 3rd floor of the administrative building. In his corner office, the CEO was the most visible of all. The top executive is expected to set an example: like 
the building, he must embody and symbolise the values. And yet, of course, he is not sovereign, but under permanent scrutiny from the board, representing the shareholders of the company.

Some have used Foucault's ideas of panopticism to argue that in modern, flexible, value-based organisations, supervision has been radicalised, that what is happening is a 'tightening of the iron cage' (Barker 1998). This is too blunt to fit realities in the glass cage. What we have here is rather a situation where bureaucratic and rational controls are being at least partly supplanted by an array of controls, which work through language, emotion, and exposure. The very transparency of the glass cage places limits to the overt authority that managers are able to exercise. The transparency suggests that at some level the walls and bars have gone, and authority has become invisible. The employees are encouraged and trained to reflect on themselves and their performance and thereby become 'self-managing'. Perhaps the 'Big Brother is watching you'-surveillance of the panopticon could be rephrased to capture a new reality of power among staff in Bang \& Olufsen: 'You are Big Brother through watching yourself and others!'- that is, by reflecting on your own performance and the performance of your teammates. This does not mean, however, that hierarchical authority has evaporated. As the US management researcher Rosabeth Moss-Kanter once observed, in the network organisation, 'restructurings make clear the realities of power' (1989: 65). In this way one might suggest a curious tension in many present-day organisations, in that they are officially and symbolically denying hierarchy while at the same time, the incessant restructurings reaffirm and are a constant reminder of the reality of such powerrelationships.

Glass is both a reflecting and a transparent medium. This duality is captured in the efforts of the organisation to reflect on and define its own fundamental values. What is more, the corporate project of reflecting on and identifying itself is not a purely reflexive, introspective exercise. It is done with the view of making public relations. As the material of glass suggests, the reflexivity is done for the purpose of being transparent toand recognised by-the outside world. Visibility, then, is not only turned inwards toward the watchtower of the prison keeper. Nor is it merely a matter of peers supervising each other in an internal, open office landscape. Instead, it is a radicalised transparency turned toward the public - the investors, and the customers. It evokes an element of exhibitionism, display, and pride-of the employee becoming part of the brand on display. But glass is also a fragile material in the sense that the glass cage is vulnerable to forces beyond the cage itself-as the financial crisis and falling stock prices in the past years has so clearly demonstrated in the case of Bang \& Olufsen.

The metaphor of glass suggests that power cannot be understood as entrapment, pure and simple. Glass also invites reflection and offers 
possibilities of exhibition and self-expression: the glass cage is not only a prison, but also a playground. It is a world where most of the employees find their work rewarding and challenging, but where they also sometimes feel that it 'eats them up'-much like academic work in the ivory tower, as noted elsewhere (Strathern 2000; Shore and Wright 1999)!

\section{The anthropology of business and the business of anthropology}

When researching matters of corporate culture, I find it important to avoid three types of a priori reductionism or theoretical 'closure'. One is the 'cultural consensus' assumption which is often the premise of the organisations' own thinking about culture, and which is also present in much of the established research on organisational culture. In this rendition culture or value based management is the magic wand that changes the 'no-win' of stifled bureaucracy to the 'win-win' of enterprise, where individual goals and corporate aims meet in sublime synthesis. The other is the opposite idea that 'culture management' is a con trick pure and simple, perpetrated by cynical managers whose only concern is the bottom-line. This last vantage point may be appealing because it provides us with the opportunity to write 'good guy/bad guy' stories. But such a setup prevents us from appreciating important, finer distinctions in the field. Furthermore, a narrative with such a crisp plot is difficult to sustain, when you find yourself in the privileged part of the world among middleclass middlemen, who, in many respects, look very much like yourself. Are they the ones 'making up' or are they the ones 'constituted through' the categories? Are they 'victims' or 'perpetrators'? If such dramatic categories make sense at all, the disquieting answer is that they -weare both.

As the above analysis has demonstrated, the distinction between the ethnographer and employees cannot be drawn easily. This is particularly clear when the anthropologist-as-researcher meets the anthropologist-consultant. It is crucial, however, that the fact that it is impossible to maintain a clear-cut separation does not imply that we should abandon the attempt to draw the line and make the distinction. On the contrary, being aware of the similarities and overlaps as well as acknowledging the differences is crucial to the kind of reflexivity, which is essential for not getting lost in the hall of mirrors. Anthropologistresearchers should refine theory and improve understanding. Business life involves particular ways of speaking and making sense of the world; specific styles of comportment, modes of conviviality and principles of judgment, which should not be taken for granted, but critically understood: For the anthropologist-researcher thick description is the ultimate aim, not efficient or appropriate intervention as is the case for the anthropologist-consultant. The point is not that 'never the twain shall 
meet'. Successful syntheses are reached all the time in collaborative projects of different kinds. But what defines the field of business anthropology is that particular tension-and the first step in making it productive is to see it and not deny it.

\section{References}

Barker, J. R. 1993 'Tightening the iron cage: Concertive control in selfmanaging teams.' Administrative Science Quarterly 38(3): 408-437.

Beolink Magazine 1999 Struer: Bang \& Olufsen.

Bourdieu, P. 1990 In Other Words. Essays Towards a Reflexive Sociology. Oxford, Polity.

Collinson, D. 1992 Managing the shopfloor: Subjectivity, masculinity, and workplace culture. Berlin, New York: Walter de Gruyter.

Du Gay, P. 1996 Consumption and identity at work. London, SAGE Publications.

Eriksen, T. H. 2001 Tyranny of the moment: Fast and slow time in the information age. London: Pluto Press.

Goffman, E. 1969 Where the action is: three essays. London: Allen Lane. Goleman, D. 2005[1996] Emotional intelligence: why it can matter more than IQ. New York: Bantham Books.

Kanter, R. M. 1989 When Giants Learn to Dance: Mastering the Challenges of strategy, management, and careers in the 1990s. London: Unwin Hyman.

Klein, N. 1999 No logo: taking aim at the brand bullies. New York, Picador USA.

Krause-Jensen, J. 2010 Flexible Firm: The design of culture at Bang and Olufsen. New York, Oxford, Berghahn Books.

Krause-Jensen, J. 2013a 'Looking into the box: Design and Innovation at Bang \& Olufsen.' Exploring creativity: evaluative practices in innovation, design and the arts. In B. Moeran and B. T. Christensen (eds.) pp. 146-171. Cambridge: Cambridge University Press.

Krause-Jensen, J. 2013b 'Counter-espionage. Fieldwork among culture experts in Bang \& Olufsen.' In Organisational Anthropology: Doing ethnography in and among complex organisations, Garsten, C. and Nyqvist, A. (eds.), pp. 43-57. London: Pluto press.

Moeran, B. and B. T. Christensen 2013 Exploring Creativity: Evaluative Practices in Innovation, Design, and the Arts. Cambridge: Cambridge University Press.

Kunde, J. 2000 Corporate religion: building a strong company through 
personality and corporate soul. London: Financial Times Prentice Hall.

Scott J. C. 1990 The Infrapolitics of subordinate groups. Domination and the arts of resistance: hidden transcripts. New Haven, Conn, London: Yale University Press.

Shore, C. and Wright, S. 1999 'Audit culture and anthropology: neoliberalism in British higher education.' Journal of the Royal Anthropological Institute, 5(4): 557-575

Strathern, M. 2000 Audit cultures: anthropological studies in accountability, ethics, and the academy. London: Routledge.

Taylor, P. and P. Bain 2003 'Subterranean Worksick Blues. Humour as Subversion in Two Call Centres.' Organisation Studies vol. 24: 1487-1509.

Weber, M. 1991 [1904] The Protestant ethic and the spirit of capitalism. London: HarperCollins.

Willis, P. E. 1997 [1977] Learning to labour: how working class kids get working class jobs. Aldershot: Ashgate.

Jakob Krause-Jensen is an anthropologist and associate professor at Aarhus University. He is interested in ways that anthropological theory and concepts and ethnographic strategies can be used to understand life in contemporary work organsations. He is the author of Flexible Firm. Design and Culture at Bang \& Olufsen (Berghahn 2010). He is also coediting (with B. Moeran) a book series-Anthropology at Work-soon to be launched by Berghahn Books. 